\title{
RESPONS MAHASISWA PENDIDIKAN BIOLOGI UIN BANDUNG TERHADAP PEMBERIAN TUGAS DI MASA PANDEMI
}

\author{
Iwan Ridwan Yusup \\ Universitas Islam Negeri Sunan Gunung Djati, Bandung \\ iwanyusup@uinsgd.ac.id
}

\begin{abstract}
ABSTRAK
Pembelajaran online adalah pembelajaran yang menggunakan jaringan internet. Dalam kegiatan belajar mengajar, segala sesuatu tidak akan lepas dari tugas, baik tugas individu maupun kelompok. Penelitian ini bertujuan untuk mengetahui respons mahasiswa Pendidikan Biologi UIN Sunan Gunung Djati Bandung terhadap penugasan selama pandemi Covid-19. Metode penelitian yang digunakan adalah metode deskriptif kuantitatif, sedangkan jenis penelitian yang digunakan adalah penelitian survei. Penelitian dilakukan pada mahasiswa pendidikan biologi dengan populasi 460 orang yang terdiri dari mahasiswa semester 1, 3, 5, dan 7. Sampel yang digunakan sebanyak 82 orang. Berdasarkan hasil uji hipotesis diketahui bahwa rasio $t_{\text {hitung }}>\mathrm{t}_{\text {tabel }}$ yaitu 97,53>1,99, sehingga dapat dikatakan respons siswa terhadap tugas saat pandemi sangat baik. Sehingga berdasarkan uji hipotesis dapat disimpulkan bahwa $\mathrm{H}_{1}$ diterima dan $\mathrm{H}_{0}$ ditolak.
\end{abstract}

Kata kunci: respons mahasiswa, tugas, studi survei, kendala

\section{BIOLOGY EDUCATION STUDENTS OF UIN BANDUNG RESPONSE ABOUT GIVING TASKS ON THE PANDEMIC PERIOD}

\begin{abstract}
Online learning is learning that uses internet networks. In teaching and learning activities, everything will not be separated from the task, be it individual or group assignments. This study aims to determine the response of the Biology Education students at UIN Sunan Gunung Djati Bandung to the assignment during the Covid-19 pandemic. The research method used is a descriptive quantitative method, while the type of research used is survey research. The study was conducted on biology education students with a population of 460 people consisting of $1 \mathrm{st}, 3 \mathrm{rd}$, 5th, and 7 th-semester students. The sample used was 82 people. Based on the results of the hypothesis test, it shows that the ratio $t_{\text {count }}>t_{\text {table }}$ is $97.53>$ 1.99, so it can be said that the student response to assignments during the pandemic is very good. So based on the hypothesis test, it can be concluded that $H_{1}$ is accepted and $H_{0}$ is rejected.
\end{abstract}

Keywords: student responses, assignments, survey studies, constraints

\section{PENDAHULUAN}

Pembelajaran daring di tengah pandemi Covid-19 ini merupakan solusi terbaik terhadap kegiatan belajar mengajar. Dalam proses pembelajaran ini pun mempunyai tujuan yang efisien guna terwujudnya aktivitas bagi mahasiswa maupun dosen dalam mengikuti mata kuliah tertentu. Menurut Niken (2020: 100), pembelajaran merupakan inti dari proses pendidikan. Kualitas pendidikan menggambarkan kualitas pembelajaran. Peningkatan kualitas pendidikan dapat dilakukan melalui peningkatan kualitas pembelajaran.

Menurut Yatimah (2017: 89) menyatakan bahwa pendidikan merupakan proses memanusiakan manusia baik dalam bentuk formal maupun informal. Pendidikan dalam bentuk formal adalah pengajaran, yaitu proses transfer pengetahuan atau usaha mengembangkan dan mengeluarkan potensi intelektualitas dari dalam diri manusia.

Untuk mencegah penyebaran Covid-19, WHO memberikan himbauan untuk menghentikan acara-acara yang dapat menyebabkan massa berkerumun. Maka dari itu, pembelajaran tatap 
muka yang mengumpulkan banyak mahasiswa di dalam kelas ditinjau ulang pelaksanaannya. Perkuliahan harus diselenggarakan dengan skenario yang mampu mencegah berhubungan secara fisik antara mahasiswa dengan dosen maupun mahasiswa dengan mahasiswa lainnya (Firman, 2020: 82). Dalam penggunaan teknologi digital dapat memungkinkan mahasiswa dan dosen melaksanakan proses pembelajaran walaupun mereka di tempat berbeda.

Bentuk perkuliahan yang dapat dijadikan solusi dalam masa pandemi Covid-19 adalah pembelajaran daring. Menurut Sadikin (2020: 215), pembelajaran daring merupakan pembelajaran yang menggunakan jaringan internet dengan aksesibilitas, konektivitas, fleksibilitas, dan kemampuan untuk memunculkan berbagai jenis interaksi pembelajaran.

Dalam kegiatan belajar mengajar, semuanya tidak akan lepas dari yang namanya tugas, baik itu tugas individu maupun kelompok. Pemberian tugas ini biasanya diberikan oleh dosen di akhir pembelajaran ataupun disampaikan di awal pertemuan yaitu pada kontrak perkuliahan. Dengan diberikannya tugas maka mahasiswa mampu berinteraksi dengan mahasiswa lainnya dalam menyelesaikan beberapa tugas yang dianggapnya penting dan merasa sulit sehingga dilakukan bersama-sama.

Berbeda dengan kondisi pendidikan saat ini yang dilakukan secara daring, semuanya serba dilakukan di rumah masing-masing tanpa bertatap muka langsung dengan dosen maupun teman. Khususnya pada prodi Pendidikan Biologi UIN Sunan Gunung Djati Bandung ini, seluruh sivitas akademika dilakukan di rumahnya masing-masing. Tugas yang didapat pun bervariasi, dimulai dari yang sulit hingga yang dirasanya mudah. Keadaan masing-masing daerah yang memiliki akses internet berbeda menyebabkan sebagian mahasiswa merasa kesulitan dalam perkuliahan juga melaksanakan tugasnya.

Dalam penelitian ini, kami mencoba mengetahui respons dari mahasiswa Pendidikan Biologi UIN Sunan Gunung Djati Bandung terhadap pemberian tugas pada masa pandemi Covid19. Dengan dilakukannya studi survei ini, kami mengetahui respons mahasiswa terhadap pemberian tugas oleh dosen selama pandemi Covid-19 ini.

\section{METODOLOGI PENELITIAN}

Metode penelitian yang digunakan ialah metode kuantitatif deskriptif, sedangkan jenis penelitian yang digunakan yaitu penelitian survei. Dalam penelitian kuantitatif deskriptif data yang diperoleh berbentuk kata-kata dan gambar seperti foto, video, rekaman suara maupun dokumen-dokumen seperti memo dan lain-lain yang didapatkan secara langsung maupun tidak langsung melalui wawancara dan catatan lapangan (Kusumawati, 2015). Menurut Singarimbun (dalam Adiyanta, 2019) dalam penelitian survei, peneliti menyediakan pertanyaan-pertanyaan mengenai laporan berupa keyakinan/kepercayaan, perilaku diri, karakteristik, harapan, pengklasifikasian ataupun pengetahuan. Pada penelitian survei biasanya pertanyaan yang diberikan mengandung variabel atau beberapa indikator, dan beberapa uji hipotesis.

Penelitian survei ini biasanya juga dimanfaatkan saat akan melakukan evaluasi, tentang seberapa jauh tujuan awal suatu program dapat tercapai hingga akhir. Selain itu hasil survei juga bisa digunakan untuk meramalkan atau memprediksi suatu fenomena sosial tertentu (Adiyanta, 2019).

Populasi dalam penelitian ini yaitu seluruh mahasiswa pendidikan biologi UIN Sunan Gunung Djati Bandung tahun ajaran 2020/2021 yang berjumlah sebanyak 460 orang, yang terdiri dari 118 orang semester tujuh, 109 orang semester lima, 116 orang semester tiga dan 117 orang semester satu. Pada penelitian kali ini, peneliti menggunakan Simple Random Sampling atau suatu teknik pengambilan sampel dari populasi secara acak tanpa memperhatika tingkatan atau strata, yang dihitung menggunakan rumus Taro Yamane atau Slovin berikut (Akdon \& Riduwan, 2009).

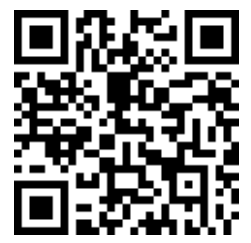

DOI PUBLIKASI https://doi.org/10.37010/int.v1i2 


\section{RESPONS MAHASISWA PENDIDIKAN BIOLOGI UIN BANDUNG

Iwan Ridwan Yusup

Universitas Islam Negeri Sunan Gunung Djati

$$
n=\frac{N}{N \times d^{2}+1}
$$

Di mana:

$\mathrm{n}=$ jumlah sampel

$\mathrm{N}=$ jumlah populasi

$\mathrm{d} 2=$ presisi (ditetapkan $10 \%$ )

$n=\frac{460}{460 \times 10 \%{ }^{2}+1}$

$=\frac{460}{460 \times 0,1^{2}+1}$

$=\frac{460}{460 \times 0,01+1}$

$=\frac{460}{4,6+1}$

$=\frac{460}{5,6}$

$=82,14 \approx 82$

Kemudian dilakukan Proportional Random Sampling untuk menentukan jumlah masing-masing sampel pada setiap tingkatan (semester) dengan rumus berikut (Akdon \& Riduwan, 2009).

$$
n i=\frac{N i}{N} \times n
$$

Di mana:

$\mathrm{n}=$ jumlah sampel keseluruhan

$\mathrm{N}=$ jumlah populasi keseluruhan

ni $=$ jumlah populasi setiap tingkatan

$\mathrm{Ni}=$ jumlah populasi setiap tingkatan

Tabel 1. Jumlah Populasi dan Sampel

\begin{tabular}{lccc}
\hline No. & Semester & $\begin{array}{c}\text { Jumlah Populasi } \\
\mathbf{( N i )}\end{array}$ & $\begin{array}{c}\text { Jumlah Sampel } \\
(\mathbf{n i})\end{array}$ \\
\hline 1. & 1 (satu) & 117 & $20,86 \approx 21$ \\
2. & 3 (tiga) & 116 & $20,67 \approx 21$ \\
3. & 5 (lima) & 109 & $19,43 \approx 19$ \\
4. & 7 (tujuh) & 118 & $21,03 \approx 21$ \\
& TOTAL & $\mathbf{N}=\mathbf{4 6 0}$ & $\mathbf{n}=\mathbf{8 2}$ \\
\hline
\end{tabular}

Teknik pengumpulan data yang digunakan ialah teknik tidak langsung dengan menggunakan instrumen penelitian berupa angket dengan alat bantu Google Form. Angket ini terdiri dari 20 butir soal yang memuat pertanyaan maupun pernyataan yang digunakan untuk memperoleh respons mahasiswa pendidikan biologi UIN Sunan Gunung Djati Bandung terhadap pemberian tugas pada masa pandemi Covid-19. Selain itu, peneliti juga menggunakan teknik pengumpulan data dengan wawancara melalui aplikasi WhatsApp. Pada penelitian ini, angket yang digunakan yaitu angket berskala likert dijawab dengan rentang skala dari 1-5 dengan interpretasi $1=$ tidak setuju; $2=$ kurang setuju; $3=$ ragu-ragu; $4=$ setuju; $5=$ sangat setuju.

DOI UNTUK ARTIKEL INI 


\section{HASIL DAN PEMBAHASAN}

\section{Hasil}

Setelah diperoleh data hasil angket, selanjutnya dilakukan perhitungan dan diperoleh rekapitulasi hasil seperti pada Tabel 2.

Tabel 2. Rekapitulasi Skor Angket

\begin{tabular}{cccc}
\hline No & Kode Responsden & Skor & Keterangan \\
\hline 1. & STSS - 7 & 56 & - \\
2. & ANJ - 7 & 59 & - \\
3. & DH - 7 & 54 & - \\
4. & SNA - 5 & 43 & Skor Terendah \\
43. & GSA - 3 & 62 &.- \\
58. & AR - 1 & 81 & Skor Tertinggi \\
$\ldots$ & $\ldots$ & $\ldots$ & $\ldots$ \\
82. & TF - 3 & 56 & - \\
\multicolumn{5}{c}{} \\
Total Skor Angket & & $\mathbf{5 0 8 0}$ \\
Rersentase Skor & & $\mathbf{6 2 , 1}$ \\
\hline
\end{tabular}

Data tersebut kemudian diolah untuk dicari perhitungan angketnya menggunakan distribusi frekuensi yang dapat dilihat pada tabel berikut.

Tabel 3. Perhitungan Angket Menggunakan Distribusi Frekuensi

\begin{tabular}{|c|c|c|c|c|c|c|}
\hline No & Kelas & $\mathbf{f}$ & Nilai Tengah (Xi) & $\mathbf{X i 2}$ & f.Xi & f.Xi2 \\
\hline 1 & $43-50$ & 3 & 46,5 & 2162,25 & 139,5 & 6486,75 \\
\hline 2 & $51-58$ & 22 & 54,5 & 2970,25 & 1199 & 65345,5 \\
\hline 3 & $59-66$ & 38 & 62,5 & 3906,25 & 2375 & 148437,5 \\
\hline 4 & $67-74$ & 17 & 70,5 & 4970,25 & 1198,5 & 84494,25 \\
\hline 5 & $75-81$ & 2 & 78 & 6084 & 156 & 12168 \\
\hline & & 82 & & & & 316932 \\
\hline \multicolumn{4}{|c|}{ TOTAL SKOR ANGKET } & \multicolumn{3}{|c|}{5080} \\
\hline \multicolumn{4}{|c|}{ RATA-RATA } & \multicolumn{3}{|c|}{62,1} \\
\hline \multicolumn{4}{|c|}{ PERSENTASE SKOR } & \multicolumn{3}{|c|}{$62,1 \%$} \\
\hline
\end{tabular}

Setelah ditemukan nilai distribusi frekuensinya, data kemudian diolah kembali untuk didapatkan simpangan bakunya seperti pada tabel berikut.

Tabel 4. Mencari Simpangan Baku

\begin{tabular}{ccccc}
\hline \multirow{2}{*}{ NO } & KODE & ReSPONSDEN & Xi-x & $(\mathbf{X i - x})^{2}$ \\
\hline
\end{tabular}

DOI PUBLIKASI https://doi.org/10.37010/int.v1i2 


\section{RESPONS MAHASISWA PENDIDIKAN BIOLOGI UIN BANDUNG \\ TERHADAP PEMBERIAN TUGAS DI MASA PANDEMI}

\begin{tabular}{ccccc}
\multicolumn{6}{c}{ Iwan Ridwan Yusup } \\
\multicolumn{5}{c}{ Universitas Islam Negeri Sunan Gunung Djati } \\
\hline 1 & STSS - 7 & 56 & $-6,1$ & 37,21 \\
2 & ANJ - 7 & 59 & $-3,1$ & 9,61 \\
3 & DH - 7 & 54 & $-8,1$ & 65,61 \\
$\ldots$ & $\ldots$ & $\ldots$ & $\ldots$ & $\ldots$ \\
82 & TF - 3 & 56 & $-6,1$ & 37,21 \\
Rata - Rata & 62,1 & & \multicolumn{2}{c}{3693,62} \\
\hline
\end{tabular}

Dari simpangan baku maka akan diperoleh simpangan baku populasi dengan menggunakan rumus sebagai berikut:

Simpangan baku populasi dengan rumus:

$\alpha=\frac{\sqrt{\sum_{i-n}^{n}(x i-X)^{2}}}{n}$

$\alpha=\frac{\sqrt{3693,62}}{82}=0,741$

Skor ideal dengan kriterium:

Skor max $\times$ Jmlh. Item soal $\times$ Jmlh. Responsden

$5 \times 20 \times 82=8.200$

Rata-rata skor ideal $=$

$\frac{\text { Skor Ideal Kriterium }}{\text { Jumlah Responden }}=\frac{8.200}{82}=100$

Nilai yang dihipotesiskan $(\mu 0)=70 \% \times$ Rata-rata skor ideal $=70 \% \times 100=70$

Jumlah anggota sampel $=82$ orang

Menentukan $t_{\text {hitung }}$ sebagai berikut (Sugiyono,2016:178):

$t_{\text {hitung }}=\frac{\overline{X-\mu 0}}{\frac{s}{\sqrt{n}}}=\frac{62,1-70}{\frac{0,741}{\sqrt{82}}}=\frac{7,9}{\frac{0,741}{9,1}}=\frac{7,9}{0,081}=97,53$

Berdasarkan hasil di atas maka dapat disimpulkan bahwa:

$t_{\text {hitung }}=97,53$

$t_{\text {tabel }}=\mathrm{dk}=\mathrm{n}-1=82-1=81$ dengan taraf kesalahan $(\alpha) 5 \%=1,99$

Maka $t_{\text {hitung }}>t_{\text {tabel }}$ artinya $\mathrm{H}_{1}$ diterima dan $\mathrm{H}_{0}$ ditolak. Ini artinya, respons mahasiswa terhadap pemberian tugas di masa pandemi sangat baik atau lebih sama dengan $70 \%$ dari yang diharapkan.

\section{Pembahasan}

Penelitian ini dilakukan dengan menyebar angket terkait respons mahasiswa dalam pemberian tugas selama masa pandemi Covid-19. Angket disebar kepada mahasiswa pendidikan biologi UIN Sunan Gunung Djati Bandung dari mulai semester 1, 3, 5, dan 7. Hasil penyebaran angket mendapat respons sebanyak 82 responden dari seluruh populasi.

Angket yang disebarkan merupakan angket yang sudah disusun oleh peneliti. angket ini divalidasi terlebih dahulu oleh dosen untuk menjamin kelayakan angket.

Dari hasil penyebaran angket diperoleh skor sebesar 5080 dengan rata-rata 62,1 dan persentase mencapai $62,1 \%$. Maka dapat diketahui bahwa respons mahasiswa terhadap pemberian tugas kuliah di masa pandemi Covid-19 dikatakan "sangat baik" terlihat dari hasil skor angket mencapai 60,2\%.

Berdasarkan hasil pengamatan, didapatkan hasil $t_{\text {hitung }}$ sebesar 92,53. Jumlah $t_{\text {hitung }}$ kemudian dibandingkan dengan jumlah $\mathrm{t}_{\text {tabel }}=\mathrm{dk}=\mathrm{n}-1=82-1=81$ dengan taraf kesalahan $(\alpha)$ $5 \%=1,99$. Berdasarkan perhitungan uji hipotesis diperoleh bahwa hasil $t_{\text {hitung }}$ lebih besar dari pada $\mathrm{t}_{\text {tabel }}$ yaitu 92,53 > 1,99, maka H1 diterima dan H0 ditolak. Berdasarkan hipotesis tersebut 
dapat disimpulkan bahwa respons mahasiswa terhadap pemberian tugas di masa pandemi sangat baik atau lebih sama dengan $70 \%$ dari yang diharapkan.

Pemberian tugas juga merupakan sebuah metode interaktif-edukatif antara pendidik dengan peserta didik. Hasil respons mahasiswa terhadap pemberian tugas ini sejalan dengan hasil analisis dalam penelitian (Efyfania, 2016), menyatakan bahwa interaksi edukatif harus menggambarkan hubungan aktif antara dua arah dengan sejumlah pengetahuan sebagai mediumnya, sehingga interaksi tersebut akan menghasilkan hubungan yang bermakna dan kreatif. Perlunya juga pengawasan terhadap mahasiswa terkait pemberian tugas dengan faktor psikolog seseorang karena dapat mempengaruhi kemampuan seseorang yang umumnya menciptakan suasana jenuh dalam pembelajaran yang dapat membuat mahasiswa mengalami penurunan dalam prestasi belajar (Rigianti, 2020: 298). Semua unsur dalam interaksi harus terikat pada tujuan pendidikan yang dirancang. Untuk tercapainya keberhasilan interaksi, dalam interaksi tersebut haruslah menciptakan respons yang baik dari siswa terhadap pemberian tugas dari guru terlebih saat belajar jarak jauh (Riska Melinda., 2020: 115). Metode pembelajaran secara daring ini dirasa oleh mahasiswa mengalami kondisi menjadi kurang fokus dan kesulitan memahami materi perkuliahan ketika proses pembelajaran berlangsung (Widodo, 2020: 106).

Selain data yang bersifat kuantitatif, dalam penelitian juga dilakukan wawancara pada beberapa sampel yang dipilih dari setiap semester. Hasil wawancara diperoleh bahwa tugas yang diberikan dosen kepada mahasiswa susah sesuai dengan RPS dan mengikuti juga memenuhi tujuan pembelajaran yang dirancang. Namun, beberapa kendala dirasakan oleh mahasiswa berupa sulitnya mencari jaringan di kampung halaman.

Mengingat pembelajaran dilakukan di daerah masing-masing dengan letak geografis yang berbeda-beda, hal ini menyebabkan jangkauan internet berbeda-beda. Kendala ini juga sedikit besarnya menghambat tingkat kecepatan mahasiswa dalam memahami materi yang disampaikan melalui media internet. Menurut Anugrahana (2020: 286) kendala yang dihadapi setiap siswa umumnya permasalahan koneksi internet yang menimbulkan keterlambatan dalam mengirimkan tugas bahkan ada yang tidak mendapat sinyal ataupun meminjam ponsel milik kerabatnya.

Menurut Imania (2019) pembelajaran daring merupakan bentuk penyampaian pembelajaran konvensional yang disajikan dalam format digital melalui internet. Dalam pelaksanaan pembelajaran daring di rumah, kurangnya sarana dan prasarana menjadi salah satu keterbatasan, seperti laptop, komputer, handphone, kuota internet, dan lain sebagainya (Anggianita, 2020: 178).

Berdasarkan pernyataan dari seluruh responden, dapat dikatakan bahwa pemberian tugas di masa pandemi sudah sesuai dengan RPS yang ditetapkan dosen. Menurut Badaruddin (2016: 55), pemberian tugas yang tidak sepantasnya dapat mempengaruhi kesehatan mental seseorang. Pemberian tugas di masa pandemi ini bagi mahasiswa semester satu lebih banyak dalam pengerjaan soal, resume, atau mind mapping. Rencana Pembelajaran Semester (RPS) dapat memenuhi kebutuhan mahasiswa dalam menguasai tema-tema yang sedang berjalan meskipun perlu penunjang lain seperti $e$-book ataupun jurnal.

Beberapa responden mengungkapkan bahwa kendala pengerjaan tugas selain jaringan juga berupa kurangnya pemahaman materi. Menurut Hutauruk (2020: 47) kendala tugas dan koneksi jaringan sangat mempengaruhi ketika proses pembelajaran dikarenakan lokasi mahasiswa yang beragam dan ketersediaan kuota. Hal ini karena pembelajaran yang dilakukan selama daring masih belum menemukan formula yang cocok baik di mata dosen ataupun mahasiswa.

Pembelajaran secara daring mengakibatkan kurang lancarnya komunikasi antar pendidik dengan peserta didik. Kebanyakan pendidik hanya memberi materi melalui aplikasi seperti Google Classroom dan membuka diskusi melalui kolom komentar. Beberapa pendidik juga

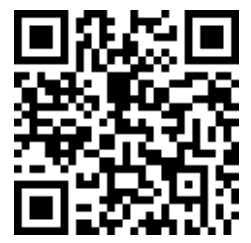

DOI PUBLIKASI https://doi.org/10.37010/int.v1i2 


\title{
RESPONS MAHASISWA PENDIDIKAN BIOLOGI UIN BANDUNG TERHADAP PEMBERIAN TUGAS DI MASA PANDEMI
}

\author{
Iwan Ridwan Yusup \\ Universitas Islam Negeri Sunan Gunung Djati
}

hanya memberikan tugas di setiap pertemuan sehingga menuntut siswa untuk belajar sendiri sementara bahan ajar yang tersedia pun sulit dipahami (Hutauruk, 2020: 47).

Pada dasarnya, pembelajaran daring tidak hanya dirasa sulit bagi mahasiswa yang menerima berbagai tugas. Hal ini juga dirasakan oleh dosen atau pengajar yang tidak kunjung menemukan model pembelajaran yang cocok sehingga menggunakan berbagai model untuk saling melengkapi guna tercapainya indikator pembelajaran. Pengajar juga tidak mengetahui sejauh mana usaha yang dilakukan peserta didik dalam upaya memahami materi.

Oleh sebab itu, pemberian tugas merupakan salah satu cara yang mau tidak mau mengharuskan peserta didik untuk terus mencari dan mempelajari sehingga lebih mudah memahami materi.

\section{PENUTUP}

Berdasarkan hasil penelitian yang diperoleh, maka dapat ditarik kesimpulan bahwa taraf signifikan respons mahasiswa Pendidikan Biologi UIN Sunan Gunung Djati Bandung tahun ajaran 2020/2021 yaitu sebesar 5080. Dengan perbandingan $t_{\text {hitung }}>t_{\text {tabel }}$ sebesar 97,53 $>1,99$ maka $\mathrm{H}_{1}$ diterima dan $\mathrm{H}_{0}$ ditolak dan dapat dinyatakan bahwa respons mahasiswa terhadap pemberian tugas di masa pandemi sangat baik atau lebih sama dengan $70 \%$ dari yang diharapkan.

Berdasarkan hasil wawancara diperoleh bahwa tugas yang diberikan dosen kepada mahasiswa telah sesuai dan mengikuti RPS yang disepakati. Sehingga, tujuan pembelajaran dapat terpenuhi melalui berbagai penugasan. Selian itu juga tentu perlu didampingi penjelasan materi untuk mendukung proses pembelajaran.

\section{DAFTAR PUSTAKA}

Adiyanta, F. S. (2019). Hukum dan Studi Penelitian Empiris: Penggunaan Metode Survey Sebagai Instrumen Penelitian Hukum Empiris. Administrative Law and Governance journal, 2(4). 697-709.

Akdon, \& Riduwan. (2009). Aplikasi Statistika dan Metode Penelitian untuk Administrasi dan Manajemen. Bandung: Dewa Ruci.

Anugrahana, A. (2020). Hambatan, Solusi dan Harapan: Pembelajaran Daring Selama Masa Pandemi Covid-19 Oleh Guru Sekolah Dasar. Jurnal Pendidikan dan Kebudayaan, Vol. 10, No. 3. Hal. 282-289.

Badaruddin, A., Erlamsyah., dan Said, A. (2016). Hubungan Kesehatan Mental dengan Motivasi Belajar Siswa. Jurnal Konselor, Vol. 5, No. 1. Hal. 50-65.

Efyfania. (2016). Studi Survei tentang Interaksi Edukatif pada Mata Pelajaran Ilmu Pengetahuan Sosial di Sekolah Dasar. Jurnal Pendidikan Dasar Perkhasa, Vol. 2, No. 1. Hal. 111112.

Firman, \& Rahayu. (2020). Pembelajaran Online di Tengah Pandemi Covid-19. Indonesian Journal of Educational Science (IJES), 2(2). 81-89.

Hutauruk, R. S. (2020). Kendala Pembelajaran Daring Selama Masa Pandemi di Kalangan Mahasiswa Pendidikan Matematika. Journal of Mathematics Education and Aplied, Vol. 2 No. 1. Hal. 54-61.

Kusumawati, M. (2015). Penelitian Pendidikan Penjasorkes. Bandung: Alfabeta.

Niken. (2020). Sistematik Review: Dampak Perkuliahan Daring saat Pandemi Covid-19 terhadap Mahasiswa Indonesia. Placentum Jurnal Ilmiah Kesehatan dan Aplikasinya, Vol. 8, No. 2. Hal. 99-108.

Purba, F. J. (2019). Pengaruh Metode Pemberian Tugas terhadap Hasil Belajar Siswa. Jurnal Inovasi Pembelajaran Fisika (INPAFI), Vol. 7, No. 1. Hal. 15-18. 
Rigianti, H. A. (2020). Kendala Pembelajaran Daring Guru Sekolah Dasar di Kabupaten Banjarnegara. Elementary School, Vol. 7. No. 2. Hal. 297-302.

Melinda, E. Y. R. (2020). Study Survei Respons Siswa dalam Pemberian Tugas Rumah (Pr) pada Masa Pandemi Covid 19. Jurnal Pendidikan Dasar Perkhasa, 6 (2), 209-216.

Sadikin Ali. 2020. Pembelajaran Daring di Tengah Wabah Covid-19. BIODIK: Jurnal Ilmiah Pendidikan Biologi. 6 (2). 214-224.

Sonia Anggianita, .. Y. (2020). Persepsi Guru terhadap Pembelajaran Daring di Sekolah Dasar Negeri 013 Kumantan. Journal of Education Research, Vol. 1 No. 2, 177-182.

Sugiyono. (2015). Metode Penelitian Pendidikan (Pendekatan Kuantitatif, Kualitatif dan R\&D). Bandung: Alfabeta.

Widodo, Arif dan Nursaptini. 2020. Problematika Pembelajaran Daring Dalam Perspektif Mahasiswa. Elementary School Education Journal, Vol. 4. No. 2. Hal. 100-115. Yatimah. 2017. Landasan Pendidikan. Jakarta: CV Alumga dan Mandiri. 